\title{
Anti-Corruption, Political Association and Enterprise Innovation
}

\author{
Mingzhe Yu \\ School of Economics \\ Central University of Finance and Economics \\ Beijing
}

\begin{abstract}
The development of enterprises can depend on two ways. On the one hand, enterprises can obtain some privileges by establishing good political connections with the government. On the other hand, enterprises can enhance their competitiveness through technological innovation. After the 18th national congress of the communist party of China (NPC), the Chinese government imposed strong sanctions on a number of government officials for corruption. This paper collects the data of Chinese listed companies from 2011 to 2013, and uses the "differencein-difference" method to study the relationship between political association and innovation of enterprises. It is found that anti-corruption policy can limit government official's protection of enterprises, reduce the incentive for enterprises to seek development through political connections, thus enhancing the incentive for enterprises to seek development through innovation, and finally improve the innovation ability of enterprises. And it's also a difference between different types of businesses, different levels of corruption.
\end{abstract}

Keywords: Anti-corruption; Political association; Enterprise innovation; DID method

\section{Introduction}

Endogenous growth theory tells us that technological progress is the source of economic growth. Under the background of accelerated integration of the global economy and China's economic transformation and upgrading, the growth mode that relies on material factor input to promote economic development cannot be sustained in the face of increasingly scarce resources and deteriorating environment. The transformation of China's economic development model from "investment-driven" to "innovation-driven" is an inevitable trend, and it is even more urgent. As a micro subject, the innovation and development of enterprises represent the innovation and development of a country. What measures should we take to improve the innovation capability of enterprises quickly? In 2006, China proposed to become an innovative country by 2020, but at this stage, the innovation capability of Chinese enterprises is still not high. On December, 2012, the Chinese government issued the "eight rules" that aimed at fighting corruption by government officials. From 1986 to 2012, on average, only 5 provincial and ministerial officials were held accountable each year, but the number of people held accountable increased to 20 in 2013 and 27 in 2014, as shown in figure 1.

Figure 1Official corruption cases in China

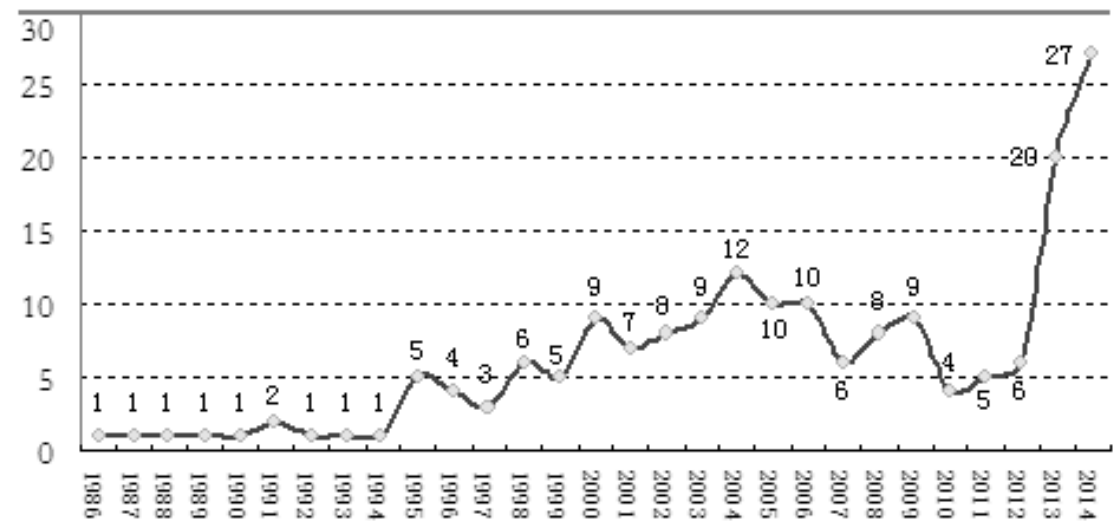

Therefore, we can use this anti-corruption campaign to study the relationship between enterprise political relations and innovation. In a particular political and economic environment, when a business is seeking development, it can either raise its own creative ability, or establish a good political relationship with the government. 
The anti-corruption action has seriously cracked down on the motivation of enterprises to seek development through political connections. Under the condition that other conditions remain unchanged, enterprises' innovation motivation will inevitably be relatively improved and their innovation ability will eventually be improved. The rest of the article is arranged as follows: the first section summarizes the existing research; The second section analyzes the relationship between political relation and enterprise innovation in theory and puts forward the theoretical hypothesis; Section 3 describes the data used in this article; The fourth quarter, using ordinary least squares method and "difference-in-difference" model for the empirical analysis; Section 5 is the conclusion.

\section{Literature Review}

In the literature on the influencing factors of enterprise innovation, some scholars study the factors at the enterprise and industry level. The famous "Schumpeter hypothesis argue that corporate R\&D activities requires constant profits support, has a monopoly enterprise in aspects such as economy of scale, risk sharing, and financing channels has a comparative advantage, also will have a stronger ability to innovate. Zhou (2005) points out that the enterprise scale, such as the innovation have a significant role in promoting, but this kind of positive relationship mainly comes from non-state-owned enterprises, rather than the state-owned enterprises, it explains the relationship between firm size and innovation to the certain condition of corporate governance structure. Aghion et al (2005) pointed out that there was an inverted U-shaped relationship between enterprise power and innovation. Competition would not only increase the extra profits of the innovation leaders, but also inhibit the innovation incentives of the laggards. Nie et al (2008) also pointed out that a certain degree of industrial competition is conducive to promoting enterprise innovation, and the innovation efficiency of private enterprises is higher than that of state-owned enterprises. The ownership reform is considered to be the important measures to improve enterprise innovation ability, such as Liu (2004) to verify the property rights reform of state-owned enterprises is improved effectively profit margins, but Bai et al (2006) also found that the phenomenon of profit margins increase is mainly due to management fee and the reducing of the financial asset ratio, rather than as a decline in the cost of unit production and the improvement of labor productivity, mainly concentrated in the early change of efficacy and did not improve the innovation ability of enterprises.

At the same time, some scholars began to realize that the fundamental reason for the low innovation efficiency of enterprises is the lack of a fair competition market environment. Lin et al (1995) pointed out that ownership discrimination and local protectionism were the main causes of unfair competition. Zhou (2007) pointed out that China's local governments and officials of local economic development has great influence and control, some important resources, administrative examination and approval, land requisition, loan guarantee, preferential policies, such as are in the hands of local governments. Close relations with the government can help enterprises to obtain government subsidies and assistance (Qian, 1988; Yu et al, 2010; Cai et al, 2011; Tian et al, 2013), or urge local governments to reduce environmental protection standards for special enterprises (Oates, 1988), or provide financing concessions to enterprises (Yu et al, 2008; Yu et al, 2012) and tax preferences (Luoet al, 2012; Li et al, 2013) either directly provide enterprises with cheap production factors (Yang, 2010) or help enterprises obtain knowledge resources from the platform of "production, study and research" (Yang et al, 2014). It can be seen that the government does not always help all enterprises in an efficient and non-discriminatory way, and officials will also use the public resources at their disposal to obtain rental income. A reasonable assumption, therefore, is that companies are more likely to win government help as long as they invest resources to establish a special political relationship with the government. When the legal environment is not perfect, the corporate property rights protection is not in place and the degree of marketization is relatively low, it can be used as an alternative protection mechanism of relevant laws and regulations to some extent, to protect the rights of enterprises and improve corporate performance(Wu et al, 2013; Zhang, 2015). Goldmam et al (2006) used the sample of S\&P500 companies from 1996 to 2000 to study the influence of political association on enterprises, they found that the stock returns of companies associated with Republicans were significantly higher than those of companies associated with Democrats. Moreover, when appointing directors with political connections, the stock market reaction of companies was usually positive. Li et al (2008) took more than 2,000 private enterprises in China as samples to test the influence of political correlation on corporate performance, they found that the membership of private entrepreneurs has a positive impact on corporate performance, which is more obvious in areas with imperfect legal protection and market development. The purpose of establishing political connections is to obtain all kinds of resources and facilities owned by the government and its subsidiary organs. However, while enjoying many benefits, enterprises will also interfere and weaken their efforts in core capacity building. 
Chen et al (2010) used the seventh national sample survey data of private enterprises to study the R\&D investment decisions of private enterprises, and found that the political relationship of private entrepreneurs has a significant negative impact on the R\&D investment tendency and $R \& D$ investment intensity of private enterprises. Luo et al (2013) used the data of Chinese listed companies from 2009 to 2011 for analysis, and found that political correlation has a significant negative relationship to the performance of technological innovation of enterprises, which reduces the investment intensity of $R \& D$ and hinders the improvement of enterprise innovation performance. Xu et al (2013) took private listed companies from 2004 to 2011 as a sample to study the impact of political uncertainty on the investment expenditure level of enterprises. They found that when faced with political uncertainty, investment expenditure of enterprises would decline significantly. Li et al (2015) used the 2012 world bank survey data to study the relationship between corruption activities and enterprise innovation, and found that there was an inverted U-shaped relationship, that is, a certain degree of corruption is the "lubricant" of enterprise innovation, but higher degree of corruption is the "stumbling block" of enterprise innovation. Jin et al (2016) used the data of 400 Chinese listed companies to test the relationship between political correlation and enterprise R\&D investment from the perspective of information asymmetry, and found that political correlation would strengthen the adverse effect of information asymmetry on enterprise R\&D investment.

Compared with the existing literature, this paper has three main contributions. First, we have deepened our understanding of corporate innovation. There are a lot of factors that can affect enterprise innovation, but if you can't eliminate the way that corporations are looking for growth through political connections, it's very difficult for them to improve their ability to innovate. Second, in the method of analysis, this article is based on an anticorruption operation based on the central government of the 18th national government, using the DID model to analyze the panel data, effectively solving the endogenous problems in the past, and verifying the causal relationship between political connections and corporate innovation. Third, we have enriched our understanding of anti-corruption. This paper studies the impact of anti-corruption on enterprises from the perspective of enterprise innovation, providing new evidence for evaluating the economic benefit of this anti-corruption action.

\section{Theoretical Analysis}

In this part, the game model is used to analyze the tradeoff between political relations and innovation.

\subsection{Description of the model}

First, assume there are $\mathrm{N}$ customers in the market, and each consumer has different preferences for product quality. A consumer with the intensity of preference for quality will get a net surplus of $\theta v-p$ by purchasing 1 unit of quality $v$ at the price of $p, \theta \in\left[\theta_{1}, \theta_{2}\right]$ and $\theta_{2}=(1+\lambda) \theta_{1}, \lambda>0$. The economic development level and income distribution pattern will affect the distribution of $\theta$, and $\theta_{1}$ will represent the lowintensity of preference of consumers and the number of them will be $\mathrm{xN} . \theta_{2}$ will represent the highintensity of preference of consumers and the number of them will be $\mathrm{yN}$. The number of intermediate consumers is $\mathrm{zN}$, and the density of $l$ is evenly distributed between $\left(\theta_{1}, \theta_{2}\right)$, and $z=1-x-y$.

Secondly, it is assumed that there are two homogenous and non-special politically-related enterprises $i$ and $j$ in a certain industry in the market during the period of 0 . When two enterprises acquire production factors at the same market price, they produce homogeneous products with the same marginal cost $c_{0}$ and the production quality is $v_{0}$, and $c_{0} \leq \theta_{1} v_{0}$. Betrand price competition is that the optimal pricing of both enterprises in the period of 0 is $\mathrm{c}_{0}$, so that they both gain half of the market share and half of the market share, and their profits are zero. It is assumed that both enterprises have $M$ resources in period 0 , which can be used to establish political connections to obtain cheap production factors, or to invest in innovative research and development to improve product quality. Therefore, when enterprises use $M$ to establish political connections, the government will give them the right to use some public resources at a low price, so that their unit production cost will be reduced to $c_{0}-s$. When the enterprise invests $M$ in innovative $R \& D$, its product quality can be improved to $v_{1}=v_{0}+\Delta v$ in period 1 . In period 1, if an enterprise cannot win profits in the market competition, it will fail and cannot recover all the resources invested or obtained in period 0. 


\subsection{General equilibrium}

Assuming that in period 0 , enterprise $i$ will use $M$ to establish political relations, while enterprise $j$ will use $M$ resources for innovation and development, which means that in period 1, enterprise $i$ will get government subsidy $\mathrm{s}$, and enterprise $j$ will get the improvement of product quality $\Delta \mathrm{v}\left(\mathrm{v}_{\mathrm{j}}>\mathrm{v}_{\mathrm{i}}\right)$, so as to set a higher price $\left(\mathrm{p}_{\mathrm{j}}>\mathrm{p}_{\mathrm{i}}\right)$. Assuming quality preference for $\theta^{*}$ of consumers to buy the two product of the enterprise is no difference, namely $\theta^{*} v_{j}-p_{j}=\theta^{*} v_{i}-p_{i}, \theta^{*}=\frac{p_{j}-p_{i}}{\Delta v}$. So quality preference for $\theta \in\left[\theta_{1}, \theta^{*}\right]$ consumers would buy products of enterprise $i$, and quality preference for $\theta \in\left[\theta^{*}, \theta_{2}\right]$ consumers will buy products of enterprise $\mathrm{j}$. In period 1 , the profit maximization problem of enterprise $i$ can be described as:

$$
\begin{aligned}
& \max _{\mathrm{p}_{\mathrm{i}}} \pi_{\mathrm{i}}=\left[\mathrm{p}_{\mathrm{i}}-\left(\mathrm{c}_{0}-\mathrm{s}\right)\right]\left[\left(\theta^{*}-\theta_{1}\right) l+\mathrm{xN}\right]-1 \text { (1) } \\
& \text { As } \frac{\partial^{2} \pi_{\mathrm{i}}}{\partial \mathrm{p}_{\mathrm{i}}^{2}}<0 \text {, The necessary condition for maximizing profit is: } \\
& \frac{\partial \pi_{\mathrm{i}}}{\partial \mathrm{p}_{\mathrm{i}}}=\left(\theta^{*}-\theta_{1}\right) l+\mathrm{xN}-\left(\mathrm{p}_{\mathrm{i}}-\mathrm{c}_{0}+\mathrm{s}\right) \frac{1}{\Delta \mathrm{v}} l=0
\end{aligned}
$$

Similarly, the profit maximization problem of $\mathrm{j}$ enterprise can be described as:

$$
\max _{\mathrm{p}_{\mathrm{j}}} \pi_{\mathrm{j}}=\left(\mathrm{p}_{\mathrm{j}}-\mathrm{c}_{0}\right)\left[\left(\theta_{2}-\theta^{*}\right) l+\mathrm{yN}\right]-1 \text { (3) }
$$

As $\frac{\partial^{2} \pi_{j}}{\partial p_{j}^{2}}<0$, The necessary condition for maximizing profit is:

$$
\frac{\partial \pi_{\mathrm{i}}}{\partial \mathrm{p}_{\mathrm{i}}}=\left(\theta_{2}-\theta^{*}\right) l+\mathrm{yN}-\left(\mathrm{p}_{\mathrm{i}}-\mathrm{c}_{0}\right) \frac{1}{\Delta \mathrm{v}} l=0 \text { (4) }
$$

Under the condition that equations (2) and (4) are established simultaneously, it can be obtained that:

$$
\begin{aligned}
& p_{i}^{*}=c_{0}+\frac{(1+x) \lambda \theta_{1} \Delta v}{3(1-x-y)}-\frac{1}{3}\left[\theta_{1} \Delta v+2 \mathrm{~s}\right](5) \\
& p_{j}^{*}=c_{0}+\frac{(1+y) \lambda \theta_{1} \Delta v}{3(1-x-y)}-\frac{1}{3}\left[\theta_{2} \Delta v-\mathrm{s}\right](6) \\
& \text { so, } \theta^{*}=\frac{\mathrm{p}_{\mathrm{j}}-\mathrm{p}_{\mathrm{i}}}{\Delta v}=\frac{(1-2 x)}{3(1-x-y)} \lambda \theta_{1}+\frac{2}{3} \theta_{2}+\frac{\mathrm{s}}{3 \Delta v}(7)
\end{aligned}
$$

However, only when the two companies have nonnegative profits, $\left(p_{i}^{*}, p_{i}^{*}\right)$ may be the pricing strategy combination of Nash equilibrium in period 1. Therefore, the sufficient and necessary conditions for enterprise $i$ to obtain non-negative profits are $\theta^{*}>\theta_{1}$ and $p_{i}^{*}>c_{0}-s$, substitute equations (5) and (7) into:

$$
\frac{s}{\theta_{1} \Delta v}>1-\frac{(1-2 x) \lambda}{(1-x-y)}(8)
$$

Similarly, the sufficient and necessary conditions for enterprise $j$ to obtain non-negative profits are $\theta^{*} \leq \theta_{2}$ and $p_{j}^{*} \geq \mathrm{c}_{0}$, substitute equations (5) and (7) into:

$$
\frac{s}{\theta_{z} \Delta v} \leq 1+\frac{(1-2 y) \lambda}{(1-x-y)(1+\lambda)}(9)
$$

If both equations (6) and (7) satisfy, then $1-\frac{(1-2 x) \lambda}{(1-x-y)}<\frac{s}{\theta_{1} \Delta v} \leq 1+\lambda+\frac{(1-2 y) \lambda}{(1-x-y)}$, so $\left(p_{i}^{*}, p_{i}^{*}\right)$ is the Nash equilibrium price strategy combination of two enterprises in period 1. At this point, the profit of enterprise $i$ is:

$$
\pi_{\mathrm{i}}=\left[\frac{(1+x) \lambda}{(1-x-y)}+\left(\frac{s}{\theta_{1} \Delta v}-1\right)\right]^{2} \frac{\theta_{1} \Delta v(1-x-y) N}{9 \lambda}-1(10)
$$

the profit of enterprise $j$ is:

$$
\pi_{\mathrm{j}}=\left[\frac{(1+x) \lambda}{(1-x-y)}+(1+\lambda)\left(1-\frac{s}{\theta_{2} \Delta v}\right)\right]^{2} \frac{\theta_{2} \Delta v(1-x-y) N}{9 \lambda}-1
$$

In the following, it is through the profits of the two enterprises in the first period that they reversely deduce whether they invest $\mathrm{M}$ in political-related construction or innovation in the period zero.

3.3 Enterprise don't make political connections

In the previous analysis, the conditions in equation (8) guarantee that enterprise $i$ can still obtain nonnegative profits in period 1 . Then, when the condition of equation (8) is not satisfied, that is:

$$
\frac{s}{\theta_{1} \Delta v} \leq 1-\frac{(1-2 x) \lambda}{(1-x-y)}
$$


Enterprise $i$ will reduce the price to $\hat{\mathrm{p}}_{i}^{*}=\mathrm{c}_{0}-s$ in order to gain market share, but if the enterprise $j$ also adjust the price to $\hat{p}_{j}$, then the condition for the loss of all market share for enterprise $i$ is:

$$
\begin{aligned}
& \theta_{1}\left(\mathrm{v}_{0}+\Delta \mathrm{v}\right)-\hat{p}_{j} \geq \theta_{1} \mathrm{v}_{0}-\hat{\mathrm{p}}_{i}^{*}=\theta_{1} \mathrm{v}_{0}-\mathrm{c}_{0}+s(10) \\
& \hat{p}_{j} \geq \mathrm{c}_{0} \text { (11) }
\end{aligned}
$$

Combining (10) and (11), enterprise $i$ was eliminated on the condition that $\hat{\mathrm{p}}_{j}^{*}=\mathrm{c}_{0}+\theta_{1} \Delta \mathrm{v}-s \geq \mathrm{c}_{0}$, or $\frac{s}{\theta_{1} \Delta v} \leq 1$.At this point, the Nash equilibrium price combination of the two companies in period 1 is $\left(\hat{\mathrm{p}}_{i}^{*}, \hat{\mathrm{p}}_{j}^{*}\right)$, enterprise $i$ not only lost the resources invest in political relations in the period of 0 , but also could not gain any benefits, $\hat{\pi}_{j}^{*}=-1$. However, since enterprise $j$ invest resources in innovation in period 0 , it is able to occupy the market independently in period 1 , and the profit is:

$$
\widehat{\pi}_{j}^{*}=\left(\widehat{\mathrm{p}}_{j}^{*}-\mathrm{c}_{0}\right) \mathrm{N}-1=\theta_{1} \Delta \mathrm{vN}-\mathrm{sN}-1 \text { (12) }
$$

Therefore, the game matrix of enterprises in period 0 can be obtained based on the profits of enterprises in period 1 , as shown in table 1.

Table 1 Game matrix of two enterprises in period 0

\begin{tabular}{|l|l|l|}
\hline $\begin{array}{l}\text { enterprise } j \\
\text { enterprise } i\end{array}$ & political association & innovation \\
\hline political association & $(-1,-1)$ & $\left(-1, \theta_{1} \Delta \mathrm{vN}-\mathrm{sN}-1\right)$ \\
\hline innovation & $\left(\theta_{1} \Delta \mathrm{vN}-\mathrm{sN}-1,-1\right)$ & $(-1,-1)$ \\
\hline
\end{tabular}

Obviously, in this case,(innovation, innovation) is the only strict dominant Nash equilibrium strategy of enterprise $i$ and $j$ in period 0.That is to say, both enterprises will use $\mathrm{M}$ for innovation and in period 0.Based on the above analysis, this paper proposes the theoretical hypothesis:"Anti-corruption" limits the protection and privileges that government officials can give to enterprises. Therefore, it reduces the incentive for enterprises to seek development through political connections, and strengthens enterprises to seek development through innovation. And the stronger the political connections of enterprises, the greater the role of "anti-corruption" in promoting enterprises' innovation.

\section{Data and Descriptive statistics}

\subsection{Sample description}

At the end of 2012, the Chinese government implemented an "anti-corruption" action, this article selects Chinese all A-share listed companies as the research object in2011-2013. According to the stock codes of listed companies in Shanghai and Shenzhen stock exchanges, enterprises in the categories of foreign capital, collective, social group and employee stock ownership committee are excluded. Enterprises with too much data missing in 20112013 were excluded. Companies with too little disclosure of executives' personal information are excluded from the prospectus. Excluding enterprises that have suffered losses for two or three consecutive years and have been specially dealt with. Excluding financial enterprises, the panel data of 3,288 samples were finally constructed. In this paper, the innovation of enterprises is taken as the explanatory variable, which is measured by the logarithm of the innovation $R \& D$ investment of enterprises. Despite the innovation of the enterprise R\&D input is not equal to enterprise innovation, most existing literature also use innovative $R \& D$ and patent number to measure together, but the patent is the result of an enterprise engaged in innovative activities, cannot reflect the anti-corruption brings to the enterprise short-term innovation incentives, so this article use the innovation of the enterprise R\&D measured by the logarithm of enterprise innovation, financial database data from the Wind.

The existing literature usually takes the political background of corporate executives as the proxy variable of corporate political association. Yu (2008) using the enterprise such as the chairman of the board of directors or general manager whether politically relevance as explained variable, Luo (2009) used the proportion of directors with political background in the board of directors to measure political correlation, while Fan et al (2007) used the political identity of CEO to measure political correlation. Because our country enterprise's chairman is often referred to as "head", actually also has the largest business decision-making power, so this article use the chairman's political identity to measure enterprise political association. Political status mainly considers whether the chairman is a party member, member of the CPPCC, representative of the NPC and political experience. 
Among them, party members only refer to the members of the communist party of China. Members of the CPPCC include members of the CPPCC national committee and local CPPCC committees. Deputies to the National People's Congress and local people's congresses; Political experience mainly refers to the experience of working in the government sector. If the chairman of the enterprise has the above characteristics, the corresponding value of the virtual variable is 1 , otherwise, the value is 0 .

At the same time, the total political correlation index of the enterprise is also constructed according to the above four identities. If the chairman of the enterprise has one of the four characteristics, the corresponding virtual variable value is 1 , otherwise, the value is 0 . The identity data is based on the information about the chairman of the board of directors in the news of Baidu, Google and the company bulletin, which is collected manually by the author.

Since this paper studies the relationship between political association and enterprise innovation by taking anticorruption as an opportunity, it is believed that the anti-corruption efforts before 2012 are weak, so the value of virtual variable of anti-corruption is 0 . After 2012, with the strong promotion of the new government, the anticorruption efforts have been strong, so the value of anti-corruption virtual variable is 1 .

In addition, Hennessy (2004) pointed out that enterprises with high asset-liability ratio usually cut investment expenditure to alleviate financial difficulties. Xin et al (2007) pointed out that the more abundant the free cash flow, the higher the level of investment expenditure; Jiang et al (2009) pointed out that corporate governance factors such as equity structure, board of directors governance and managers' shareholding would also influence the investment behaviors of enterprises. Therefore, in this paper, the rate of assets and liabilities of the enterprise, the net cash flow per share, return on invested capital and enterprises attributes, such as age, enterprise scale variables as control variables of the model, at the same time also to join enterprises and annual control variables in the model. The data came from the Wind financial database.

\subsection{Descriptive statistics}

Table 2 Descriptive statistics of variables

\begin{tabular}{|l|l|l|l|l|l|}
\hline name & number & mean & variance & minimum & maximum \\
\hline R\&D & 3288 & 17.2742 & 1.7841 & 8.0063 & 22.8651 \\
\hline Party & 3288 & 0.7198 & 0.4491 & 0 & 1 \\
\hline CPPCC & 3288 & 0.0976 & 0.2969 & 0 & 1 \\
\hline NPC & 3288 & 0.2408 & 0.4277 & 0 & 1 \\
\hline Political experience & 3288 & 0.1041 & 0.3053 & 0 & 1 \\
\hline Political association & 3288 & 0.7198 & 0.4491 & 0 & 1 \\
\hline Enterprise property & 3288 & 0.4689 & 0.4991 & 0 & 1 \\
\hline Enterprise age & 3288 & 15.5093 & 4.4023 & 2 & 34 \\
\hline Enterprise scale & 3288 & 179050.4 & 490599.7 & 6245.8 & $1.21 \mathrm{e}+07$ \\
\hline Asset liability \% & 3288 & 47.6158 & 22.2799 & 0.708 & 299.177 \\
\hline Cash flow per share & 3288 & 0.0126 & 0.7576 & -6.2516 & 7.0447 \\
\hline
\end{tabular}

\section{Empirical Analysis}

In this paper, I adopt the DID method to study the relationship between political association and innovation of enterprises separately. The specific estimation equation is as follows:

Innovation $_{\text {it }}=$

$\alpha_{0}+\alpha_{1}$ Political $_{i} \times$ anti $_{t}+\alpha_{2}$ Political $_{i}+\alpha_{3}$ anti $_{t}+$ $\rho$ Control $_{i t}+\gamma$ Control $_{i}+$ $\lambda \mu+\theta z+\eta_{i t}$

(13)

Where, $a n t i_{t}$ represents anti-corruption virtual variable. If the time is after 2013 (including 2013), then anti $_{t}=1$; otherwise, anti $i_{t}=0$. Political $_{i} \times$ anti $_{t}$ represents the cross term. At this time, $\alpha_{1}$ measures the causal effect of political correlation on enterprise innovation. Table 3 reports the estimation results of the DID model. 
Table 3 Anti-corruption and Innovation

\begin{tabular}{|l|l|l|l|l|}
\hline \multirow{2}{*}{$\begin{array}{l}\text { Independent } \\
\text { variable }\end{array}$} & \multicolumn{4}{|l|}{ Dependent variable: enterprise R\&D cost } \\
\cline { 2 - 5 } & $(1)$ & $(2)$ & $(3)$ & $(4)$ \\
\hline Political $_{i} \times$ anti $_{i}$ & -0.233 & $0.295^{* *}$ & $0.521^{* * *}$ & $0.415^{* * *}$ \\
\hline & $(0.144)$ & $(0.122)$ & $(0.0948)$ & $(0.109)$ \\
\hline Political $_{i}$ & -0.0932 & -0.137 & $-0.334^{*}$ & $-0.446^{* *}$ \\
\hline & $(0.118)$ & $(0.175)$ & $(0.184)$ & $(0.182)$ \\
\hline anti $_{t}$ & -0.0932 & 0.183 & 0.281 & 0.433 \\
\hline & $(0.118)$ & $(0.272)$ & $(0.223)$ & $(0.474)$ \\
\hline Controlvariable & & Yes & Yes & Yes \\
\hline Industry & & & Yes & Yes \\
\hline Area & & & & Yes \\
\hline Number & 3288 & 3288 & 3288 & 3288 \\
\hline
\end{tabular}

Note: the robust standard error is shown in brackets. $* * * p<0.01, * * p<0.05$, ${ }^{*} \mathrm{p}<0.1$.

I use political associated virtual variables, anti-corruption, and cross terms in the regression equation. In table 3 , column (4)shows that after controlling the control variables of industry fixed effect and enterprise fixed effect, the anti-corruption associated with total political cross terms has a significant positive effect on enterprise innovation, corruption has a positive effect on enterprise innovation but not significantly, political association has a negative effect on enterprise innovation, which means that the anti-corruption action significantly enhances the innovation of political associated enterprises. Moreover, the greater the anti-corruption intensity and the higher the political correlation degree, the greater the innovation incentive, which confirms the theoretical hypothesis put forward by the game model above. This paper continues to use the virtual variables of political association constructed above to analyze the influence of political association on enterprise innovation of different ownership natures. Table 4 reports the estimation results of the dual difference model between state-owned enterprises and private enterprises.

Table 4 Anti-corruption and Innovation (state-owned and private)

\begin{tabular}{|c|c|c|c|c|}
\hline \multirow{3}{*}{$\begin{array}{l}\text { Independent } \\
\text { variable }\end{array}$} & \multicolumn{4}{|c|}{ Dependent variable: enterprise $R \& D$ cost } \\
\hline & \multicolumn{2}{|c|}{ state-owned } & \multicolumn{2}{|l|}{ private } \\
\hline & $(1)$ & (2) & (3) & (4) \\
\hline \multirow[t]{2}{*}{ Political $\times$ anti $_{6}$} & 0.495 & $0.759 * * *$ & $0.165^{*}$ & $0.263 * *$ \\
\hline & $(0.375)$ & $(0.142)$ & $(0.0878)$ & $(0.123)$ \\
\hline \multirow[t]{2}{*}{ Political } & -0.390 & $-0.362 * *$ & 0.116 & 0.251 \\
\hline & $(0.314)$ & $(0.145)$ & $(0.225)$ & $(0.157)$ \\
\hline \multirow[t]{2}{*}{ anti $_{t}$} & 0.433 & 0.503 & 0.293 & 0.153 \\
\hline & $(0.349)$ & $(0.469)$ & $(0.315)$ & $(0.214)$ \\
\hline Control variable & & Yes & Yes & Yes \\
\hline Industry & & Yes & & Yes \\
\hline Area & & Yes & & Yes \\
\hline Number & 1614 & 1614 & 1453 & 1453 \\
\hline
\end{tabular}

Note: the robust standard error is shown in brackets. $* * * p<0.01$, $* * p<0.05,{ }^{*} \mathrm{p}<0.1$.

In table 4, columns (1) and (2) show that for state-owned enterprises, the coefficient of the virtual variable of anticorruption, the political correlation and the cross-term of the mare all positive, they are indicating that "anticorruption" action improves the innovation of state-owned enterprises. Similarly, columns (3) and (4) show that for state-owned enterprises, the coefficient of the virtual variable of anti-corruption, the political correlation and the cross-term of the mare all positive, they are indicating that "anti-corruption" action improves the innovation of private enterprises. However, state-owned enterprises are more effective than private enterprises.

\section{Conclusion}

With the continuous occurrence of anti-corruption action, there is no unified judgment on whether anti-corruption is conducive to economic growth and how to evaluate the economic impact of this anti-corruption action. This paper provides evidence for the positive influence of anti-corruption on economic development from the perspective of enterprise innovation. 
Therefore, in order to further improve the independent innovation ability of enterprises, the government should continuously weaken the incentive for enterprises to seek development through political connections. For example, reducing the government's direct control of market resources, allowing the market to play a decisive role in allocating resources; Reduce the government's administrative approval authority, eliminate government officials from enterprises to seek rent opportunities. Only in this way can we fully release the positive impact of this anticorruption campaign and guide the sound development of enterprises.

\section{References}

Aghion, P., Bloom, N., Blundell, R., Griffith, R., Howitt, P., "Competition and. Innovation: An Inverted U Relationship", [J]Quarterly Journal of Economics, 2005, 20(2):701 -728.

Goldman, E. and J. Rocholl, “Does Political Connectedness Affect Firm Value?”,[R] University of North Carolina at Chapel Hill, 2006.

Li, H., L. Meng, Q. Wang, and L. Zhou, "Political Connections, Financing and Firm Performance: Evidence from Chinese Private Firms", [J]Journal of Development Economics, 2008,87(2): 283-299

Oates, W. E. and R. M. Schwab, "Economic Competition among Jurisdictions: Efficiency Enhancing or Distortion Inducing?", [J]Journal of Public Economics, 1988,35, 333-354.

Qian, Y. and G. Roland, "Federalism and the Soft Budget Constraint", [J] American Economic Review, 1998, 88(5):1143-1162.

Schumpeter, J. A., Capitalism, Socialism and Democracy, New York, 1942

Zhou L, Luo K, "Enterprise size and innovation: Empirical evidence from China's provincial level" ,[J] Economics (Quarterly), 2005,3.

Nie H, Tan S, Wang Y, "Innovation, enterprise scale and market competition: Panel data analysis at the Chinese enterprise level", [J] World Economy, 2008, 7.

Liu xiao-hyun, "The Chinese industrial enterprises' ownership structure has influenced the difference in efficiency of the national industrial census data in 1995",[J] Economic Research, 2000, 2.

Bai Chongen, Lu Jiangyong, Tao Zhigang, "Empirical research on the effect of state-owned enterprise restructuring", [J] Economic Research, 2006, 8.

Zhou Lian, "A study on the promotion of local officials in China”, [J] Economic Research, 2007, 7.

Yu Minggui, Pan Hongbo, "Political relations, institutional environment and private enterprise bank loans", [J] The World of Management, 2008, 8.

$\mathrm{Yu}$ Wei, Wang Miaojun, Jin Xiangrong, "Political connections and financing constraints: Information effect and resource effect", [J]Economic Research, 2012, 9.

Luo Dang, Wei Zhu, "Research on political connections and tax avoidance by private enterprises: Empirical evidence from listed companies in China", [J]Southern Economy, 2012, 11.

Li Weian, Xu Yicun, "Tax avoidance effect of political identity”, [J] Financial Research, 2013,3.

Yang Qijing, "Decentralization, growth and inequality", [J] World Economy, 2010, 4.

Yang Shengsheng, Yu Feng, "Mechanism research on the influence of political connections on enterprise innovation",[J]Nankai Economic Research, 2014, 6.

Zhang Tianshu, Chen Xinyuan, Huang Jun, "Political association, venture capital investment and enterprise performance", [J] Nankai Management Review, 2015,5.

Wu Keping, Yu Fusheng, "Institutional environment, political relations and accounting information quality", [J] Journal of Shanxi University of Finance and Economics, 2013, 11. 